Publisher: GSA

Journal: GEOL: Geology

DOI:10.1130/G37144.1

\title{
1 Controls on transgressive sill growth
}

\section{Richard J. Walker}

3 Department of Geology, University of Leicester, University Road, Leicester LE1 7RH,

$4 \quad U K$

\section{ABSTRACT}

Igneous sills represent an important contribution to upper crustal magma transport

7 and storage. This study focuses on an exemplary 20-50-m-thick transgressive sill in the

8 Faroe Islands, on the European Atlantic passive margin, which is hosted in layered lavas

9 (1-20 m thick) and basaltic volcaniclastic units (1-30 m thick). Preserved steps in the sill,

10 and offset intrusive segments, are consistent with initial propagation as segmented

11 fractures, followed by inflation to create a through-going sheet. Although steps

12 correspond to the position of some host rock interfaces and volcaniclastic horizons, most

13 interfaces are bypassed. Transgressive sill contacts are sub-parallel to thrust faults that

14 record ENE-WSW shortening, which are observed within the surrounding country rock,

15 and within the sill. Remnant sill segments are elongate along a NNW-SSE axis, parallel

16 to the derived intermediate stress axis for thrust faults. The overall transgressive

17 geometry is consistent with regional horizontal shortening, with steps indicating

18 transitions between transgressive and lateral sill propagation controlled locally by

19 layering. This work emphasizes the importance of scale of observation in considering the

20 controls on sill emplacement, and in particular, that layering is not the primary control on 21 geometry.

\section{INTRODUCTION}


Publisher: GSA

Journal: GEOL: Geology

DOI: $10.1130 / \mathrm{G} 37144.1$

Igneous sills represent an important contribution to upper crustal magma transport

24 (e.g., Airoldi et al., 2011; Muirhead et al., 2014), acting as magma conduits and stores.

25 Sill emplacement in basin settings can impact subsurface fluid flow (e.g., water aquifer

26 and hydrocarbon systems: Gudmundsson and Løtveit, 2012), and the maturation of

27 hydrocarbons (Malthe-Sørenssen et al., 2004). Large volumes of transgressive, saucer-

28 shaped sills are identified in three-dimensional (3-D) seismic data sets across basin

29 systems (e.g., Thomson and Hutton, 2004), and show that individual sills comprise a

30 series of lobes that record phases of sill propagation. Field-based observations of saucer-

31 shaped sills (e.g., Polteau et al., 2008; Schofield et al., 2010, 2012), indicate that these

32 lobes may also comprise smaller structures, such as segmented elongate fingers, which

33 record phases of inflation and linkage during intrusion. Both observation scales have

34 invoked the role of host rock strength in controlling sill geometry, but it should be noted

35 that 3-D seismic resolution is too low to make this critical correlation. This paper

36 highlights stress controls on transgressive sill emplacement, exemplified in the Faroe

37 Islands (Fig. 1; Fig. DR1 in the GSA Data Repository ${ }^{1}$ ), on the European Atlantic

38 margin. Detailed mapping shows that the Streymoy sill (Fig. 1) intruded as segmented

39 fractures, which inflated and linked to create a stepped, through-going sheet. Overall

40 geometry is controlled by regional stress, with local propagation controlled by layering,

41 but there is no strict relationship between sill steps and "weak" units or layer interfaces.

42 These observations have direct importance to transgressive sills identified in volcanic

43 sub-systems, and particularly studies that infer major effects of intrusion, on host rock

44 properties or maturation (e.g., Svensen et al., 2004).

45 FAROE ISLANDS TRANSGRESSIVE SILLS 
Publisher: GSA

Journal: GEOL: Geology

DOI:10.1130/G37144.1

The Faroe Islands host several transgressive sills that intrude near-horizontal ( 0

$473^{\circ}$ dip) basaltic lavas and volcaniclastic units of the Palaeocene-age Malinstindur, Sneis,

48 and Enni Formations (oldest to youngest; Fig. 2). The Malinstindur Formation is

49 dominated by 1-3-m-thick compound basalt lavas that are commonly separated by

50 volcaniclastic sandstone units ( $<2 \mathrm{~m}$ thick), but which account for $<10 \%$ of the sequence

51 where studied. The Sneis Formation is entirely volcaniclastic, ranging from sandstones to

52 conglomerates, with a total thickness ranging from 1 to $30 \mathrm{~m}$ (Passey and Jolley, 2008).

53 The Enni Formation comprises interbedded simple ( 2-20-m-thick) and compound ( 1-

543 -m-thick) lavas, and $<2$-m-thick volcaniclastic sandstone units. Fault and fracture

55 characterization through this sequence (Walker et al., 2013) shows that strain is

56 accommodated through initial brittle failure in lavas, and ductile flow within

57 volcaniclastic sandstone units, highlighting contrasting mechanical properties within the

58 sequence. This paper focuses on the Streymoy sill (see e.g., Hansen et al., 2011), which

59 covers $\sim 17 \mathrm{~km}^{2}$, with a vertical extent of $\sim 480 \mathrm{~m}$. Hansen et al. (2011) separated the sill

60 into two broad 'saucer' shapes, which were referred to as the northwest and southeast

61 segments (Fig. 1A). Thickness ranges from 20 to $30 \mathrm{~m}$ in the northwest segment, and 40

$6250 \mathrm{~m}$ in the southeast segment. The estimated pre-erosion volume is $\sim 2 \mathrm{~km}^{3}$ (Hansen et

63 al. 2011). Erosion has resulted in variable incision through the stratigraphy, and the sills

64 can be identified in the topography by roches moutonées (Fig. 2B). Mapping of the top

65 and bottom sill contacts, and inclined sheets associated with the sill, where this style of

66 erosion has not occurred, shows that roches moutonées are parallel to steps in the sill, and

67 are estimated to be within $\sim 1 \mathrm{~m}$ of the original sill contact.

68 INTRUSION GEOMETRY 
Publisher: GSA

Journal: GEOL: Geology

DOI:10.1130/G37144.1

The Streymoy sill southeast segment shows evidence of a 'saucer-shaped'

70 geometry, displaying a flat inner region and a transgressive periphery, which locally dips

$71 \leq 35^{\circ}$ (e.g., Figures 1B and 2A). As shown in Figure 2, however, closer inspection of the

72 sill reveals that it transgresses as a series of inclined sections (dipping $7-35^{\circ}$ ), which are

73 separated by flat sections (dipping $0-3^{\circ}$ ). Flat sections have lateral extents (parallel to

74 dip) of $\sim 300-350 \mathrm{~m}$ where observed (e.g., Figures $2 \mathrm{~A}$ and $2 \mathrm{C}$ ). Inclined sections

75 accommodate a range of transgression scales, from $\sim 60 \mathrm{~m}$ (e.g., Fig. $2 \mathrm{~B}$ ), to $\sim 250 \mathrm{~m}$ (e.g.,

76 Figures 2A and 2B) measured parallel to dip. Sill contacts on transgressive sections

77 display regular undulations (Figs. 2C and 3), with the top contact showing consistent

78 wavelengths of $\sim 40-60 \mathrm{~m}$ and amplitudes ranging from 5 to $25 \mathrm{~m}$, and bottom contacts

79 showing a stepped geometry at the same scale (Figs. 2B, 2C, and 3C). Individual steps in

80 the basal contact cannot be measured, but top contact steps in the form of roches

81 moutonées are continuous for 220-310 m laterally (Fig. 1).

82 Although flat sections of individual steps correspond to some lava unit interfaces

83 or volcaniclastic units, including those of the Sneis Formation (Fig. 2), individual sill

84 steps transect most units and unit interfaces. It is important to note also that overall, the

85 sill 'flat' sections dip at $0-3^{\circ} \mathrm{W}$, whereas host units in the study area, dip $2-3^{\circ} \mathrm{E}$, so "flat"

86 sections of the sill are still mildly transgressive through the stratigraphy. For example, the

87 large sill flat sections correspond locally to the position of the volcaniclastic Sneis

88 Formation, but the lowermost part of the flat occurs $\sim 10-20 \mathrm{~m}$ stratigraphically below it,

89 within Malinstindur Formation lavas (Fig. 2B).

90 The sill and host rock are cut by a network of conjugate northeast- and southwest-

91 dipping, millimeter-to-centimeter displacement, calcite- and zeolite-mineralized thrust 
Publisher: GSA

Journal: GEOL: Geology

DOI: $10.1130 / \mathrm{G} 37144.1$

92 faults that dip sub-parallel to the inclined sections of the sill (Figs. 2A and 2C), however,

93 it is noted that steps do not correspond to the position of thrusts, nor do the thrusts

94 accommodate sufficient displacement to account for the scale of the steps. Thrusts dip in

95 the range $20-40^{\circ} \mathrm{SW}$, and $5-30^{\circ} \mathrm{NE}$. Walker et al. (2011) showed that those thrust faults

96 accommodated ENE-WSW to northeast-southwest contraction (see Figure 2C inset), and

97 are associated with strike-slip faults that accommodate an east-west contraction, and

98 north-south extension (see Figure 2B inset). The sills cut conjugate dikes that also

99 accommodate east-west contraction and north-south extension, indicating that the sills

100 were emplaced during a regional east-west compression. Calculated palaeostress axes

101 (e.g., Figures 2B and 2C insets) correlate well with sill geometry in that (1) sill contacts

102 are sub-parallel to conjugate thrust faults, and form an acute angle to the calculated $\sigma_{1}-\sigma_{2}$

103 plane for those thrusts (e.g., Fig. 2C), and (2) relict sill segments are elongate parallel to

104 the calculated $\sigma_{2}$ axis for conjugate thrust faults (NNW-SSE).

105 Steps observed on the contacts of the Streymoy sill (e.g., Fig. 3B) are consistent

106 with step features observed in dikes (e.g., Pollard et al., 1975), sills (e.g., Schofield et al.,

107 2012), and echelon joint and vein sets (e.g., Pollard et al., 1982). In such cases, steps are

108 shown to result from linkage of offset or en echelon intrusion or fracture segments, which

109 coalesce to a single sheet. Segmented sill-parallel minor intrusions (Fig. 3a), and sill

110 internal contacts (Figs. 2A and 3C), are inferred here to record the early stages of

111 intrusion as segments, ahead of a through-going sheet.

\section{CONTROLS ON TRANSGRESSIVE SILL GEOMETRY}

113 Numerical models for centrally-fed sills emplaced into isotropic elastic media

114 (e.g., Malthe-Sørenssen et al., 2004), and analogue models for intrusion using 
Publisher: GSA

Journal: GEOL: Geology

DOI: $10.1130 / \mathrm{G} 37144.1$

115 homogenous media (e.g., Galland et al., 2009) indicate that transgressive 'saucer-shaped'

116 sills are a fundamental shape in shallow systems. Malthe-Sørenssen et al. (2004) showed

117 that the development of a saucer shape, from an established flat sill, is strongly controlled

118 by stress asymmetry ahead of the propagating crack tip: the sill would propagate as a flat

119 intrusion until it had spread to a radius approximately equal to the depth of emplacement,

120 when doming in the overburden would affect a tensile stress asymmetry ahead of the tip,

121 leading to upward propagation. These experiments were conducted using isotropic media,

122 which indicates transgression is controlled by overburden deformation, rather than host

123 mechanical layering. This point is supported by observations of the Streymoy sill. For

124 instance, the broad 'flat' part of the sill shown in Figure 2C, does not directly exploit the

125 Sneis Formation contacts. The implication is that although the layered host sequence may

126 promote horizontal propagation of the sill, that layering plays a secondary (albeit locally

127 important) role in the overall sill geometry.

128 Steps observed in the Streymoy sill contacts, and in minor sheets adjacent to the

129 sill (e.g., Fig. 3A), are interpreted to represent sill propagation as a series of segmented

130 fractures, which inflated and linked to create a through-going sheet. Studies of fracture

131 and fault propagation in elastic multilayers (e.g., Schöpfer et al., 2006; Walker at al.,

132 2013) have shown that during regional extension, fractures develop initially in the

133 mechanically "stronger" (brittle) units, before linking through "weaker" (ductile) units as

134 strain increases. Walker et al. (2013) showed that faults cutting interlayered (basaltic)

135 volcaniclastic-lava sequences develop initially through brittle failure in the lava, and

136 ductile flow within volcaniclastic units. The result of this early-developed fracture

137 architecture is that the through-going faults display significant steps. A similar effect 
Publisher: GSA

Journal: GEOL: Geology

DOI:10.1130/G37144.1

138 could occur during regional compression, with fractures developing sub-horizontally

139 rather than sub-vertically. Layer-bound fracturing could also lead to fractures propagating

140 preferentially in (NNW-SSE horizontal) the $\sigma_{2}$ axis, rather than growing in the

141 (southeast-plunging) $\sigma_{1}$ axis, as a result of individual fractures being impeded by existing

142 discontinuities. Transgressive steps in the sill occur at the meter to tens of meters scale,

143 associated with thin-unit boundaries (e.g., 1-3-m-thick compound lavas and sediments:

144 Fig. 3A), and at the hundred-meter scale, associated with thick-unit boundaries (e.g., the

145 Sneis Formation: Fig. 2C). The implication here is that the sill intruded as cracks that

146 inflated to form a through-going sheet, but that vertical propagation of individual

147 segments was locally impeded by mechanical contrasts (such as strength, Poisson's ratio,

148 and Young's modulus) in the host sequence (Fig. 4). Sill steps may therefore preserve the

149 initial strain gradient from a through-going portion of the transgressive sill, with NNW-

150 SSE horizontal intrusion and inflation only possible once cracks becomes connected to

151 the source. Host mechanical properties therefore play an important role in the local

152 propagation and segmentation of the sill, either in focusing propagation (e.g., along unit

153 interfaces), or by impeding propagation across mechanical layers or discontinuities, but

154 the overall geometry is a record of the northeast-southwest compression.

155 AN ALTERNATIVE MODEL FOR TRANSGRESSIVE SILL EMPLACEMENT

156 The transgressive geometry of the Streymoy sill, combined with evidence for

157 local mechanical control in the early development of the sill as segments, is consistent

158 with the development of a shallowly-dipping hydrofracture system, similar to that

159 described by Baer (1995). In that model, intrusion by brittle fracture involved phases of

160 fracture propagation ahead of the leading edge of the magma, followed by tip fluid 
Publisher: GSA

Journal: GEOL: Geology

DOI: $10.1130 / \mathrm{G} 37144.1$

161 propagation, and conduit flow. I infer here that emplacement of the Streymoy sill can be

162 summarized into four stages (Fig. 4):

163 (1) Regional ENE-WSW contraction and NNW-SSE extension, coupled with magmatic

164 pressure-driven failure in the host rock, facilitated horizontal propagation of a flat

165 elliptical sill (Fig. 4A), sub-parallel with the $\sigma_{1}-\sigma_{2}$ plane (i.e., gently WSW-dipping)

166 related to regional horizontal shortening.

167 (2) As the radius of the elliptical sill reached a value approximately equal to the depth of

168 emplacement, doming of the overburden resulted in asymmetric tensile stress ahead

169 of the propagating sill tip, facilitating an upward deflection (Fig. 4B).

170 (3) Host mechanical layering resulted in preferential fracture and fault development in

171 elastically compliant layers (i.e., layers with a lower resistance to fracture), leading to

172 NNW-SSE layer-bound fracture propagation parallel to $\sigma_{2}$ (Figs. 4C and 4Di).

173 (4) As strain increased through inflation, transgressive fracture tips linked individual sill

174 segments to create a through-going sill (Figs. 4Dii and 4Diii).

175 It is important to note that "layering" in this case, may refer to sequences of units,

176 such as multiple lavas, rather than individual units. As with studies in fault systems (e.g,

177 Schöpfer et al., 2006) the extent of individual segments (as measured in the dip direction)

178 during initial sill propagation is related to the thickness of the host layering and reflects

179 the distribution of existing fractures in the host rock (Fig. 4C). Upward propagation in

180 stage 2 could lead to a reduction in magma pressure and flexural strain at the sill

181 periphery (Malthe-Sørenssen et al., 2004). This would promote magma propagation as

182 flat-lying sills that preferentially exploit bedding planes (e.g., Fig. 4D). This type of

183 effect has been proposed elsewhere in discussion of flat outer rims on sills (e.g., Goulty 
Publisher: GSA

Journal: GEOL: Geology

DOI: $10.1130 / \mathrm{G} 37144.1$

184 and Schofield, 2008; Airoldi et al., 2011). Flat zones are observed in the Streymoy sill at

185 various elevations (e.g., Figures $2 \mathrm{~A}$ and $2 \mathrm{~B}$ ), which may be explained by this mechanism,

186 but it is noted that flat sections of the sill cut through a number of unit interfaces,

187 including the formation boundary between the Malinstindur Formation compound lavas,

188 and the sedimentary Sneis Formation.

\section{CONCLUSIONS}

190 The Streymoy sill is an exemplary transgressive sill formed during horizontal

191 shortening. Although the sill is hosted in mechanically layered units, the broad geometry

192 is consistent with models for emplacement in an isotropic medium. Steps indicate that

193 mechanical layering is important in controlling local propagation and contact geometry,

194 which is important when considering processes associated with transport and storage of

195 magma in the subsurface. Notably, major sedimentary horizons in the lava-dominated

196 sequence are not preferentially intruded, but still impose geometric controls on the sill.

197 The mechanical contrast here is comparable to sandstone-mudstone sequences, in which

198 sandstones represent the stronger material. Most steps are below seismic imaging scales,

199 emphasizing the importance of the scale of observation in understanding intrusion

200 emplacement controls and mechanisms.

\section{ACKNOWLEDGMENTS}

202 Observations crucial to this study were made during Walker's Ph.D. research,

203 which was funded by Statoil (UK) Ltd. Thanks to Ken McCaffrey, Bob Holdsworth, and

204 Richard England, and Nick Schofield and the anonymous reviewers for very detailed

205 reviews that greatly benefit the paper. Thanks to the Føroya Dàtusavn for access to aerial 206 imagery. 
Publisher: GSA

Journal: GEOL: Geology

DOI:10.1130/G37144.1

\section{REFERENCES CITED}

208 Airoldi, G., Muirhead, J.D., White, J.D.L., and Rowland, J.V., 2011, Emplacement of

209 magma at shallow depth: insights from field relationships at Allan Hills, south

210 Victoria Land, East Antarctica: Antarctic Science, v. 23, p. 281-296, doi:10.1017/S0954102011000095.

212 Baer, G., 1995, Fracture propagation and magma flow in segmented dykes: Field

213 evidence and fabric analysis, Makhtesh Ramon, Israel, in Baer, G., and Heinmann,

214 A.A., eds., Physics and Chemistry of Dykes: Rotterdam, Netherlands, A.A. Balkema,

215 p. $125-140$.

216 Galland, O., Planke, S., Neumann, E.R., and Malthe-Sørenssen, A., 2009, Experimental

217 modelling of shallow magma emplacement: Application to saucer-shaped intrusions:

218 Earth and Planetary Science Letters, v. 277, p. 373-383,

219 doi:10.1016/j.epsl.2008.11.003.

220 Goulty, N., and Schofield, N., 2008, Implications of simple flexure theory for the formation of saucer-shaped sills: Journal of Structural Geology, v. 30, p. 812-817, doi:10.1016/j.jsg.2008.04.002.

223 Gudmundsson, A., and Løtveit, I.F., 2012, Sills as fractured hydrocarbon reservoirs:

224 Examples and models, in Spence, G.H., et al., eds., Advances in the Study of

225 Fractured Reservoirs: Geological Society of London Special Publication 374, p.

$226 \quad 251-271$.

227 Hansen, J., Jerram, D.A., McCaffrey, K.J.W., and Passey, S.R., 2011, Early Cenozoic

228 saucer-shaped sills of the Faroe Islands: An example of intrusive styles in basaltic 
Publisher: GSA

Journal: GEOL: Geology

DOI: $10.1130 / \mathrm{G} 37144.1$

lava piles: Journal of the Geological Society, v. 168, p. 159-178, doi:10.1144/0016-

$230 \quad 76492010-012$.

231 Malthe-Sørenssen, A., Planke, S., Svensen, H., and Jamtveit, B., 2004, Formation of

232 saucer-shaped sills, in BreitKreuz, C., and Petford, N., eds., Physical Geology of

233 High-Level Magmatic Systems: Geological Society of London Special Publication,

234234, p. 215-227.

235 Muirhead, J.D., Airoldi, G., White, J.D.L., and Rowland, J.V., 2014, Cracking the lid:

236 Sill-fed dikes are the likely feeders of flood basalt eruptions: Earth and Planetary

237 Science Letters, v. 406, p. 187-197, doi:10.1016/j.epsl.2014.08.036.

238 Passey, S.R., and Jolley, D.W., 2008, A revised lithostratigraphic nomenclature for the

239 Palaeogene Faroe Islands Basalt Group, NE Atlantic Ocean: Transactions of the

240 Royal Society of Edinburgh, Earth and Environmental Science, v. 99, p. 127-158,

241 doi: $10.1017 /$ S1755691009008044.

242 Pollard, D.D., Muller, O.H., and Dockstader, D.R., 1975, The form and growth of

243 fingered sheet intrusions: Geological Society of America Bulletin, v. 86, p. 351-363,

244 doi:10.1130/0016-7606(1975)86<351:TFAGOF>2.0.CO;2.

245 Pollard, D.D., Segall, P., and Delaney, P.T., 1982, Formation and interpretation of

246 dilatant echelon cracks: Geological Society of America Bulletin, v. 93, p. 1291-

$247 \quad$ 1303, doi:10.1130/0016-7606(1982)93<1291:FAIODE $>2.0 . C O ; 2$.

248 Polteau, S., Ferre, E.C., Planke, S., Neumann, E.-R., and Chevallier, L., 2008, How are

249 saucer-shaped sills emplaced? Constraints from the Golden Valley Sill, South Africa:

250 Journal of Geophysical Research, v. 113, B12104, doi:10.1029/2008JB005620. 
Publisher: GSA

Journal: GEOL: Geology

DOI: $10.1130 / \mathrm{G} 37144.1$

251 Schofield, N., Stevenson, C., and Reston, T., 2010, Magma fingers and host rock

252 fluidization in the emplacement of sills: Geology, v. 38, p. 63-66,

253 doi:10.1130/G30142.1.

254 Schofield, N., Brown, D.J., Magee, C., and Stevenson, C.T., 2012, Sill morphology and 255 comparison of brittle and non-brittle emplacement mechanisms: Journal of the

256 Geological Society, v. 169, p. 127-141, doi:10.1144/0016-76492011-078.

257 Schöpfer, M.P.J., Childs, C., and Walsh, J.J., 2006, Localisation of normal faults in

258 multilayer sequences: Journal of Structural Geology, v. 28, p. 816-833,

259 doi:10.1016/j.jsg.2006.02.003.

260 Sperner, B., Ratschbacher, L., and Ott, R., 1993, Fault-Striae analysis: a Turbo Pascal

261 program package for graphical presentation and reduced stress tensor calculation:

262 Computers \& Geosciences, v. 19, p. 1361-1388, doi:10.1016/0098-3004(93)90035-

2634.

264 Svensen, H., Planke, S., Malthe-Sørenssen, A., Jamtveit, B., Myklebust, R., Rasmussen

265 Eidem, T., and Rey, S.S., 2004, Release of methane from a volcanic basin as a

266 mechanism for initial Eocene global warming: Nature, v. 429, p. 542-545,

267 doi:10.1038/nature02566.

268 Thomson, K., and Hutton, D., 2004, Geometry and growth of sill complexes: Insights

269 using 3D seismic from the North Rockall Trough: Bulletin of Volcanology, v. 66,

270 p. $364-375$, doi:10.1007/s00445-003-0320-z.

271 Walker, R.J., Holdsworth, R.E., Imber, J., and Ellis, D., 2011, Onshore evidence for

272 progressive changes in rifting directions during continental break-up in the NE 
Publisher: GSA

Journal: GEOL: Geology

DOI: $10.1130 / \mathrm{G} 37144.1$

273 Atlantic: Journal of the Geological Society, v. 168, p. 27-48, doi:10.1144/0016-

$274 \quad 76492010-021$.

275 Walker, R.J., Holdsworth, R.E., Imber, J., Faulkner, D.R., and Armitage, P.J., 2013, Fault

276 zone architecture and fluid flow in interlayered basaltic volcaniclastic-crystalline

277 sequences: Journal of Structural Geology, v. 51, p. 92-104,

$278 \quad$ doi:10.1016/j.jsg.2013.03.004.

\section{FIGURE CAPTIONS}

280 Figure 1. The Streymoy Sill, Faroe Islands. A: Aerial image showing the positions and

281 inferred extent of the northwest and southeast segments (after Hansen et al., 2011). B:

282 Hill-shaded topographic image (illuminated from 315) with color-coded elevation for the

283 exposed areas of the sill. C: Aerial image showing color-coded slope (dip) data for the

284 exposed areas of the sill.

285

286 Figure 2. Cross sections through the Streymoy sill: view-fields shown in Figure 1C. A:

287 View northwest to the southernmost outcrops of the southeast segment, showing the

288 overall northeast and southwest transgressive nature of the sill. Insets show (i) variable

289 attitudes of joints within the sill, and (ii) stepping basal contact of the sill. Horizontal

290 rock exposures correspond to lava core zones, showing that sill steps do not correspond

291 to individual lava interfaces. B: Northwest segment shows a stepped transgression up to

292 the northeast. Note that the photo perspective means that the left of the image is oriented

293 northeast-southwest, and the right of the image shows northwest-southeast. C: Cross

294 section through the northwest segment of the sill, showing relationship to inclined

295 "feeder" dikes (after Hansen et al., 2011), and thrust faults. Lower hemisphere 
Publisher: GSA

Journal: GEOL: Geology

DOI:10.1130/G37144.1

296 stereographic projection insets are for (B) faults within the lava host rock (left) and

297 calculated principal compressive stress axes (where $\sigma_{1}>\sigma_{2}>\sigma_{3}$ ) with the maximum

298 horizontal compression direction (right), and (C) thrust faults (left) and calculated

299 principal stress axes (right). Principal stress attitudes were calculated using the simple

300 shear tensor average method (Sperner et al., 1993). Fmn-Formation.

301

302 Figure 3. Intrusion segments, and relict segments. A: Inclined intrusion (see Figure 2C

303 for location) is segmented and discontinuous in this cross section. Segment tips are

304 commonly spatially associated with host unit interfaces, though individual segments also

305 cut a number of host contacts. B: Transgressive and flat parts of the southeast segment

306 show steps at the meter and tens of meter scales. C: Internal contact in the southeast

307 segment (location shown in Fig. 2A). D: Oblique cut-through of a transgressive part of

308 the southeast segment (location indicated in Fig. 1C). Relict segments are elongate

309 northwest-southeast. The sill is accommodated by $\sim 50 \mathrm{~m}$ of apparent vertical uplift of the

310 host stratigraphy, whereas the sill thickness measured normal to the margins is $\sim 30 \mathrm{~m}$.

311

312 Figure 4. Conceptual model for the propagation of the Streymoy sill. A-C: Maps (left)

313 and cross sections (right). See text for details. A: Flat, elliptical sill emplacement. B:

314 Overburden doming results in upward deflection of the crack tip. C: Transgression and

315 propagation of the sill is controlled locally by mechanical layering. D: Inflation of

316 fractures leads to linkage, forming a through-going sheet. Panels i-iii show the

317 progressive stages of inflation from fractures to a linked sheet.

318 
Publisher: GSA

Journal: GEOL: Geology

DOI: $10.1130 / \mathrm{G} 37144.1$

319 GSA Data Repository item 2016xxx, xxxxxxxx, is available online at

320 www.geosociety.org/pubs/ft2016.htm, or on request from editing@geosociety.org or

321 Documents Secretary, GSA, P.O. Box 9140, Boulder, CO 80301, USA. 
Fig. 1

W: $123 \mathrm{~mm}$

H: $52.6 \mathrm{~mm}$

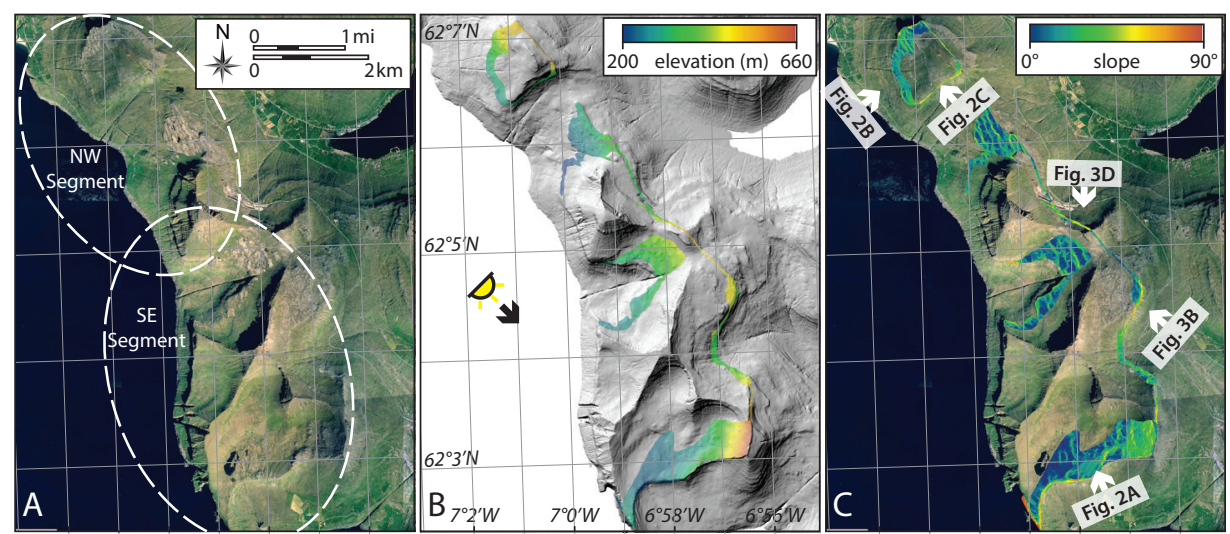


Fig. 2

$\mathrm{W}: 123 \mathrm{~mm}$

$\mathrm{H}: 95 \mathrm{~mm}$

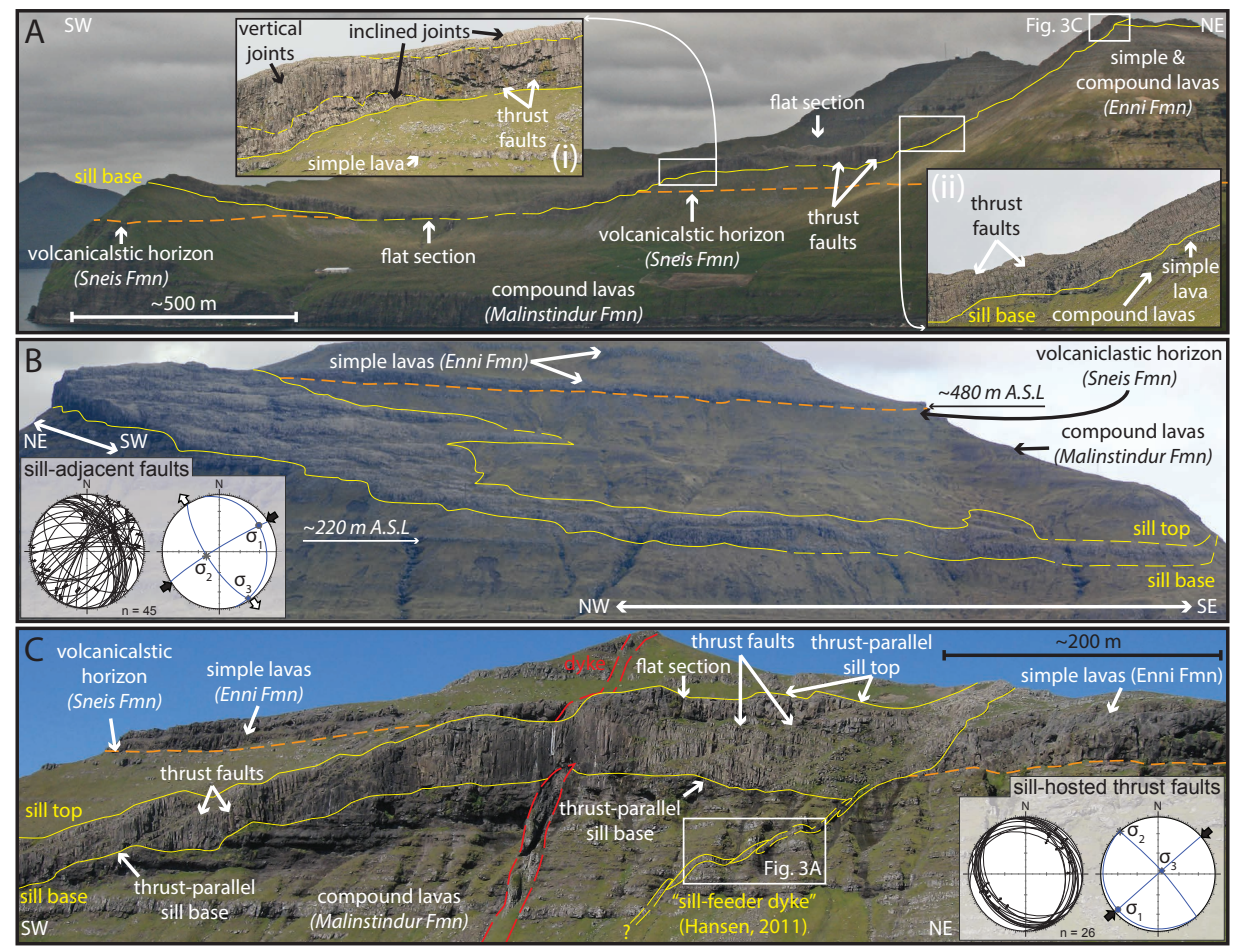


Fig. 3

W: $123 \mathrm{~mm}$

$\mathrm{H}: 106 \mathrm{~mm}$

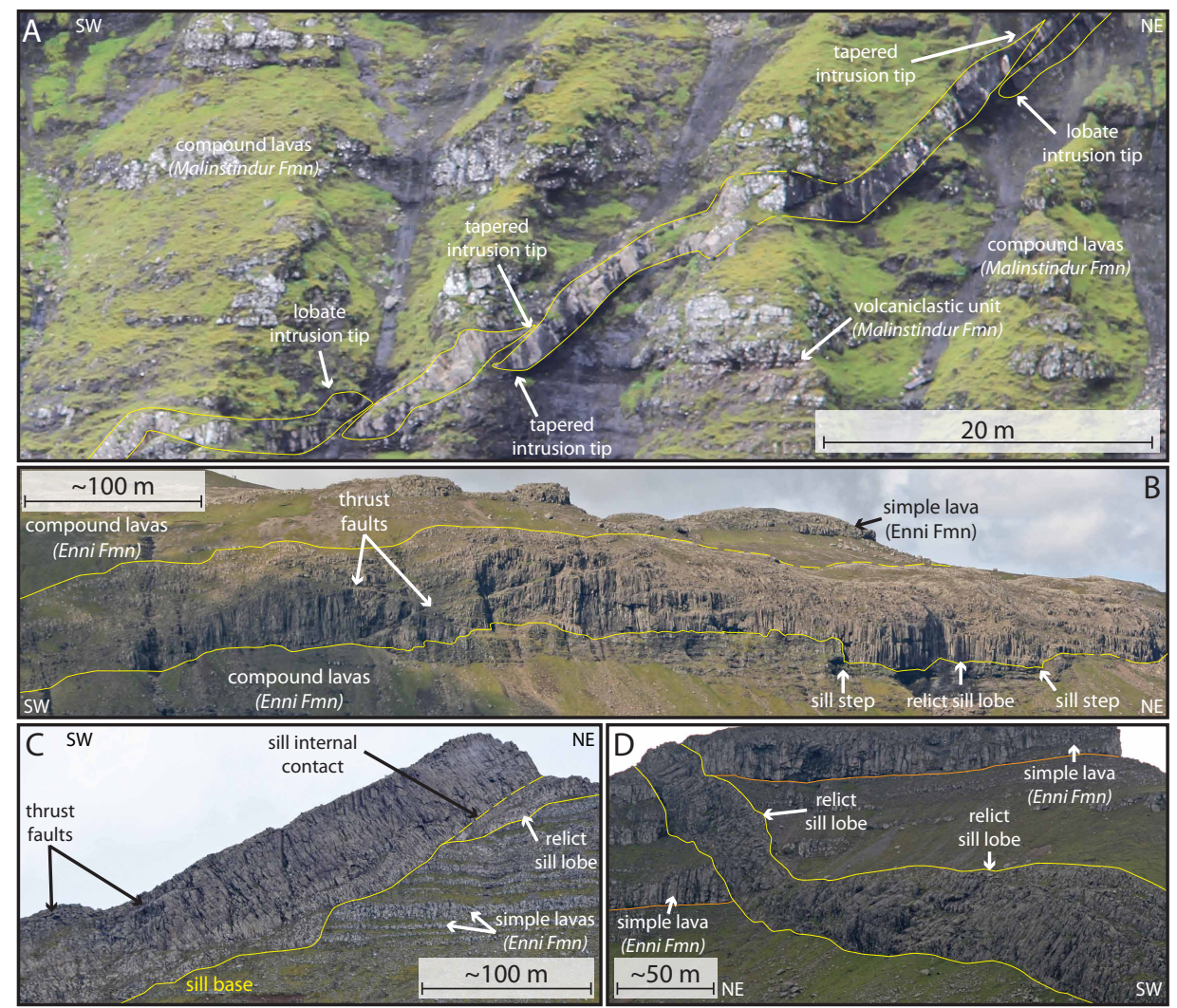


Fig. 4

W: $61 \mathrm{~mm}$

$\mathrm{H}: 101 \mathrm{~mm}$
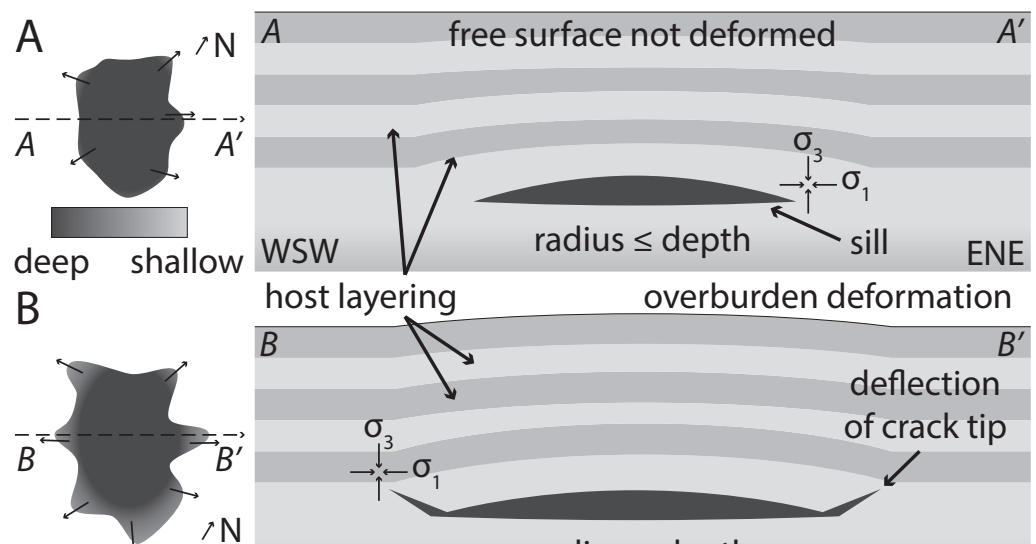

host layering overburden deformation

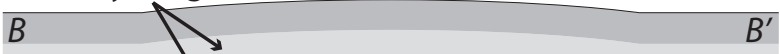

deflection

of crack tip

$>\mathrm{N}$
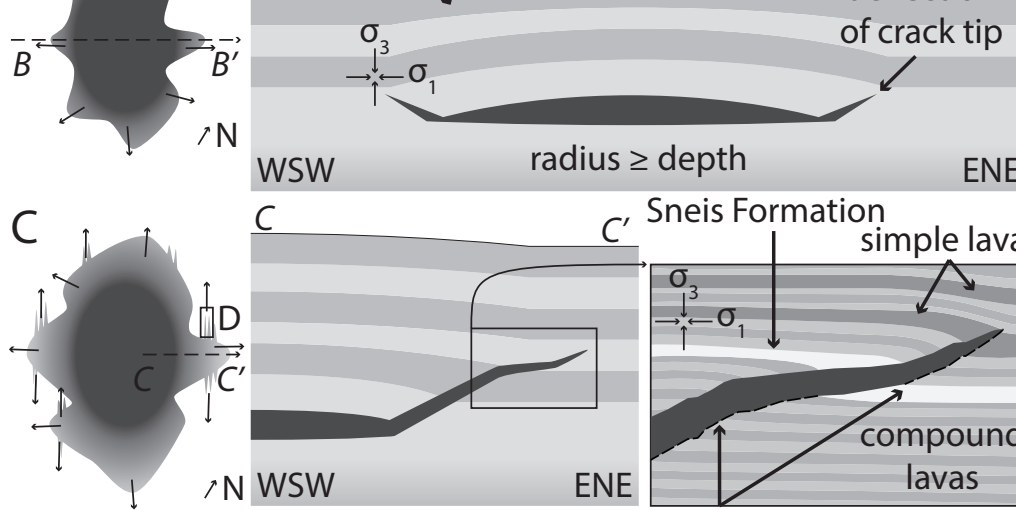

WSW

radius $\geq$ depth

ENE

C C, Sneis Formation

simple lava

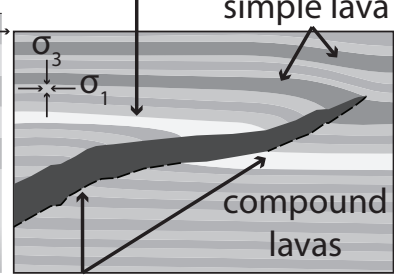

N WSW

ENE

lavas

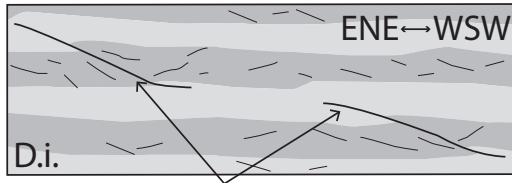

pre-sill fault segments (see D.i.) transgressive

propagation flat

D

fault segments ahead of sill

tip (linked in/out

of section)

tip line

segment inclined
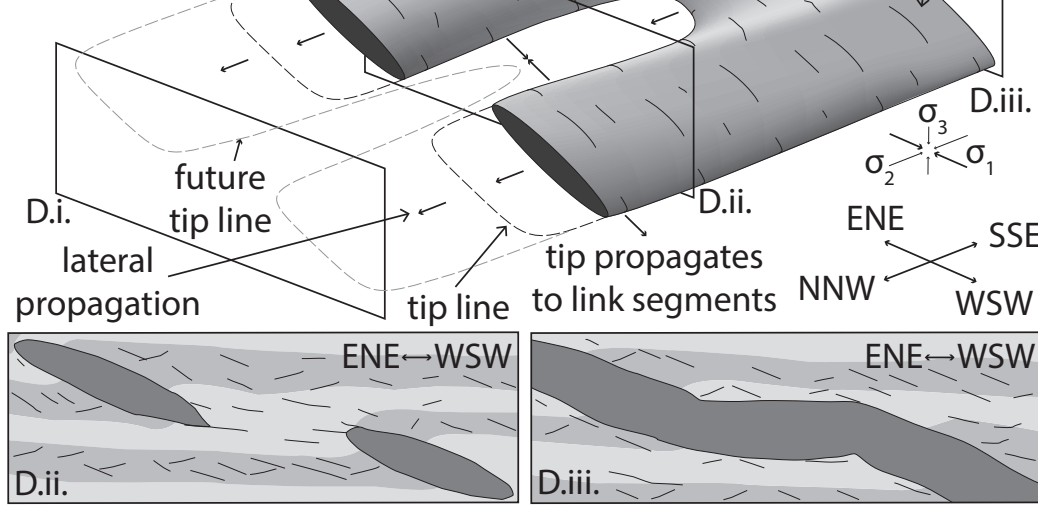